DOI : $10.14746 /$ pp.2015.20.4.9

\title{
Beata SŁOBODZIAN
}

Gdańsk

\section{Sukces czy porażka społeczności lokalnych? - funkcjonowanie jednostek pomocniczych, na przykładzie miasta Gdańska}

\begin{abstract}
Streszczenie: Jednostki pomocnicze miasta Gdańska stały się trwałym elementem w jego przestrzeni. Przyjęte rozwiązania prawne nie obligują władz miasta do tworzenia jednostek pomocniczych (np. w Gdyni jest obowiązek powolywania jednostek pomocniczych), ale kwestie te są wynikiem oddolnego działania mieszkańców. Mechanizm kształtowania instytucji jednostek pomocniczych stał się formą partycypacji obywateli w życiu gminy. Specyficzne funkcjonowanie gdańskich jednostek pomocniczych polega na ich ciaglej przemianie, spowodowanej zmianami prawa lokalnego, poszukiwaniem "idealnych" rozwiązań. Zadawalające jest to, iż wiele poczynań władz miasta zmierza do ustabilizowania i poprawy jakości funkcjonowania jednostek pomocniczych.
\end{abstract}

Słowa kluczowe: samorząd, jednostki pomocnicze, partycypacja

\section{Wprowadzenie}

- amorząd jest najstarszą formą organizacji życia społecznego. Istniał od zarania - ludzkości, od czasu, gdy ludzie zaczęli łączyć się w grupy, aby we współdziałaniu z innymi skuteczniej zaspokajać swe potrzeby. Ulegał on licznym zmianom, tak jak w procesie historycznym zmieniały się społeczeństwa.

Zapoczątkowany w 1990 r. proces przekształceń ustrojowych przyczynił się do powstania samorządu terytorialnego na poziomie podstawowym - gminnym. Przyjęte rozwiązania prawne (w początkowej fazie) dotyczące ustroju, funkcjonowania, zadań i kompetencji gminy były zadawalające. Sukcesywnie uchwalane nowe ustawy (bądź nowelizowane już obowiązujące) uszczegółowiły i doprecyzowały proces decentralizacji (Słobodzian, 2007, s. 46-50). Powstałe samorządowe gminy otrzymały prawo do podejmowania decyzji właściwych dla zaspokojenia potrzeb swojej wspólnoty (np. realizacja zadań własnych, stanowienie prawa lokalnego, pozyskiwanie środków finansowych - dochody własne).

Zgodnie z zapisem ustawy z 8 marca 1990 r. o samorzqdzie gminnym ${ }^{1}$ - „gmina może tworzyć jednostki pomocnicze: sołectwa oraz dzielnice, osiedla i inne. Jednostką pomocniczą może być również położone na terenie gminy miasto" (art. 5 ust. 1). Regulacja ta pozwoliła na dokonywanie reorganizacji wewnątrz gminy - podziału jej terytorium na mniejsze struktury przestrzenne oraz „tworzenie” ciał (organów) zarządzających na tych mikroobszarach. Brak uszczegółowienia przepisów ustawy spowodował, iż ich doprecy-

${ }^{1}$ Ustawa z 8.03.1990 r. o samorzadzie gminnym, tekst jednolity Dz. U. 2013, Nr 594, poz. 1318 ze $\mathrm{zm}$ 
zowanie odbywało się (i nadal odbywa) na poziomie prawa lokalnego - w treści statutów gmin, uchwałach, zarządzeniach. Skutkiem takiego rozwiązania było m.in. zróżnicowanie nazewnictwa jednostek pomocniczych (głównie w miastach, gdyż na wsiach zachowała się historyczna nazwa - sołectwo), zasady i tryb wyborów organów w jednostkach pomocniczych, procedura zatwierdzania statutów, mechanizm sprawowania nadzoru i kontroli nad jednostkami.

Reforma administracji publicznej wprowadzona w życie od 1 stycznia 1999 r., rozszerzenie procesu decentralizacji - utworzenie samorządowego powiatu i województwa, zmiana zasad wyboru organu wykonawczego $\mathrm{w}$ gminie (od $2002 \mathrm{r}$.) przyczynity się do wzrostu zainteresowania sprawami lokalnymi i uaktywnienia społeczności lokalnych. Przejawiało się to także w coraz większym zainteresowaniu funkcjonowaniem jednostek pomocniczych.

\section{Ksztaltowanie się jednostek pomocniczych miasta Gdańska}

Od 1 stycznia 1999 r. miasto Gdańsk (dotychczasowa stolica województwa gdańskiego), zgodnie z założeniami nowej reformy administracji publicznej, otrzymało status miasta na prawach powiatu (tzw. miasta grodzkiego) i zachowało status stolicy województwa - w nowym układzie terytorialnym - pomorskiego.

Nowo wybrane (w 1998 r.) władze miasta - Prezydent Miasta oraz 60-osobowa Rada Miasta Gdańska rozpoczęły „zarządzanie" miastem z wykorzystaniem istniejącej siatki podziału terytorium miasta na jednostki pomocnicze. Wpisały się one na trwałe w strukturę przestrzenną miasta, gdyż ułatwiały realizację zadań samorządowych, wspomagały zarządzanie miastem jako całością, a przede wszystkim stanowiły element historii miasta ${ }^{2}$.

W 1990 r. „usamorządowiony” Gdańsk - miasto-gmina - jego terytorium stanowiło jednorodną całość. Pierwszy podział administracyjny na jednostki pomocnicze nastąpił w 1992 r. Rada Miasta Gdańska uchwałą z 30 lipca 1992 r. w sprawie utworzenia jednostek pomocniczych Miasta Gdańska w postaci dzielnic/osiedli (Uchwała 1992, XLI) utworzyła 29 jednostek. Ich granice terytorialne określono przebiegiem ulic, a szczegółowy ich wykaz sporządził Zarząd Miasta. Wyodrębniono nazwy „,dzielnica”, „osiedle”, których rozróżnienie stanowiła liczba mieszkańców. Osiedlem określano tę jednostkę pomocniczą, na obszarze której musi zamieszkiwać nie mniej niż 2000 mieszkańców, dzielnica - to jednostka pomocnicza, której obszar zamieszkiwany jest przez nie mniej niż 20000 mieszkańców (Statut Miasta Gdańska). Następstwem utworzenia jednostek pomocniczych miały być działające na ich obszarze organy władzy, pochodzące z bezpośrednich wyborów rady dzielnic/osiedli i wyłaniane drogą pośrednią - zarządy.

Przyjęta przez Radę Miasta uchwała „,wyborcza” (Uchwała 1992 XLIX) w 1992 r. nie została wprowadzona w życie. Mimo regulacji prawnej, normującej procedurę wyborczą nie przeprowadzono wyborów do rad dzielnic/osiedli. Powodem był brak inicjatywy mieszkańców w celu utworzenia rady dzielnicy/osiedla.

\footnotetext{
${ }^{2}$ Wiele z dzielnic i osiedli Gdańska powstało jako samodzielne wsie w wiekach średnich. Także ich nazwy mają historyczne znaczenie.
} 
Pierwsze wybory do rad dzielnic/osiedli odbyły się 29 czerwca 1997 r. Wybrano tylko trzy rady: Radę Osiedla Rudniki, Radę Osiedla Letnica, Radę Osiedla Osowa na kadencję jednoroczną, gdyż w 1998 r. odbywały się wybory do organów stanowiących samorządu terytorialnego ${ }^{3}$.

W latach 1992-1997 w funkcjonowaniu jednostek pomocniczych (podziale administracyjnym miasta) dokonywano licznych zmian, głównie w wielkości obszaru terytorialnego i nazewnictwie jednostek:

a) osiedla Przymorze Małe i Przymorze Wielkie połączono w Przymorze (Uchwała 1992, LV);

b) z Olszynki-Błonia (z Płonią) utworzono osiedle Zawodników i Olszynkę Południe-Błonia (Uchwała 1993, LIX), którą w 1995 r. rozdzielono na Olszynkę Południe i Rudniki-Błonia (z Płonią) (Uchwała 1995, XXIII);

c) w 1997 r. powrócono do podziału Przymorza na Przymorze Małe i Przymorze Wielkie, Olszynkę Południe i Osiedle Zawodników połączono w Olszynkę a Rudnikom-Błonia (z Płonią) zmieniono nazwę na Rudniki (Uchwała 1997, XLV).

Glównym argumentem wysuwanym przez inicjatorów zmian była niejednorodność struktury urbanistycznej i społecznej, szczególne powiązanie terenów (mieszkańców) infrastrukturą urządzeń działających na ich terenie, instytucjami kultury, placówkami edukacji, służby zdrowia ${ }^{4}$. Należy wspomnieć, że budowane w latach siedemdziesiątych i osiemdziesiątych XX w. osiedla mieszkaniowe (np. Zaspa, Rozstaje, Morena, Przymorze) stanowily integralną całość. Osoby otrzymujące mieszkania były pracownikami głównie Stoczni Gdańskiej, zakładów produkujących dla stoczni. Pracownicy ci (mieszkańcy) stanowili zintegrowaną społeczność, którą łączyło miejsce zamieszkania i pracy. Stąd propozycje zmian w układzie terytorialnym (podział na jednostki pomocnicze), wyłonienia władz jednostki uznawano za zbyteczne i godzące w ich wspólnotę.

Istotne zmiany nastapiły w $1998 \mathrm{r}$. - roku przygotowywania założeń reformy administracji publicznej oraz wyborów samorządowych. 11 października 1998 r., równolegle z wyborami do Rady Miasta Gdańska i Sejmiku Województwa Pomorskiego odbyły się wybory do 6 rad osiedli. Tylko w 6 jednostkach pomocniczych mieszkańcy podjęli inicjatywę, celem której było wyłonienie w wyborach lokalnych liderów. Obowiązujące przepisy uchwały Rady Miasta Gdańska (Uchwała 1998, LXII) dotyczące wyborów do rad dzielnic/osiedli wprowadzały wymóg $15 \%$ frekwencji przy urnach, by wybory były ważne. W 5 osiedlach frekwencja wyborcza przekroczyła 33, a w Nowym Porcie - 26\%.

Wyniki wyborów (wielkość frekwencji) świadczyć może o dużej akceptacji mieszkańców dla powołania władz osiedla, wysokim zaangażowaniu się inicjatorów osiedla, pobudzeniu poczucia wspólnotowości. Z drugiej strony, $15 \%$ próg frekwencji zniechęcał do aktywności, dla wielu mieszkańców (osiedlowych działaczy) był barierą nie do przekroczenia, a tym samym uzasadniał rezygnację ze starań o powołanie władz dzielnicy/osiedla.

W 1999 r. rada Miasta Gdańska złagodziła przepisy wyborcze, zmieniając wielkość progu frekwencji z 15 na 10\% (Uchwała 1999, LX). Zmiana ta umożliwiła realizację kolejnych wyborów:

\footnotetext{
${ }^{3}$ Zgodnie z prawem, kadencja rad dzielnic/osiedli kończy się wraz z upływem kadencji Rady Miasta Gdańska.

${ }^{4}$ Zob. uzasadnienia do uchwał Rady Miasta Gdańska zmieniających podział na jednostki pomocnicze.
} 
a) w 1999 r. wybrano przedstawicieli do Rady Osiedla: Strzyża (frekwencja 15,03\%), Brzeźno (16,61\%), Stogi z Przeróbką (15,74\%);

b) w 2000 r. wybrano Radę Osiedla Kokoszki (22,92\%), Radę Osiedla Wzgórze Mickiewicza $(17,07 \%)$.

W 2002 r. - roku wyborów samorządowych do organów stanowiących oraz po raz pierwszy - na wójta, burmistrza, prezydenta miasta, gdańscy radni podjęli uchwałę (Uchwała 2002, XLIX) zmieniającą wysokość progu frekwencji wyborczej. Przywrócono $15 \%$ próg wyborczy. Liczono, iż bezpośrednie wybory na prezydenta miasta zmotywują mieszkańców do większego zaangażowania się w proces wyborczy, a tym samym ułatwią wybranie radnych dzielnicy/osiedla. Czyli, że przekroczenie $15 \%$ progu frekwencji nie będzie kłopotliwe, a tym samym zadba się o lepszą (bo wyższą niż 10\%) jakość wyborcza.

Efektem wprowadzenia 15\% progu frekwencji było nieprzeprowadzenie wyborów do rad dzielnic i osiedli. Sytuacja ta pokazała, że nie należy lekceważyć mieszkańców, przyznawać im prawa, które zmienia się bez ich udziału (brak konsultacji społecznych). Swoisty „bunt” mieszkańców w przerwaniu cyklu wyborczego do rad dzielnic/osiedli przyczynił się do kolejnej zmiany lokalnych przepisów wyborczych.

W 2003 r. nowo wybrani radni miejscy przegłosowali i przyjęli uchwałę (Uchwała 2003, VIII) zmieniającą wysokość progu frekwencji wyborczej. Mocą tej uchwały ponownie obniżono próg do $10 \%$. W uzasadnieniu uchwały czyta się, iż „w związku z licznymi wnioskami mieszkańców Gdańska dotyczącymi obniżenia progu frekwencji dla uzyskania ważności wyborów w jednostkach pomocniczych dokonuje się jego zmiany".

Obniżenie progu frekwencji spowodowało uznanie za ważne wyborów do rad dzielnic/osiedli, które odbyły się 18 maja 2003 r. w następujących jednostkach: Brzeźno $(11,99 \%)$, Letnica $(17,50 \%)$, Krakowiec-Górki Zachodnie $(22,35 \%)$, Wyspa Sobieszewska $(18,66)$, Rudniki $(22,38 \%)$, Wzgórze Mickiewicza $(15,68 \%)$, Kokoszki $(11,23 \%)$, Strzyża $(11,92 \%)$, Osowa $(11,41 \%)$, Olszynka $(20,19 \%)$.

Nikłe zainteresowanie wyborami wykazali mieszkańcy: Nowego Portu $(6,15 \%)$, Stogów (z Przeróbką) - 9,69\%, Chełmu (z Dzielnicą Gdańsk Południe) - 3,47\%.

Dnia 5 czerwca 2005 r. mieszkańcy osiedla Młyniska wybierali swoich radnych. Frekwencja wyborcza wyniosła $15,68 \%$.

Po kolejnych wyborach samorządowych przypadających na 12 listopada 2006 r. rozpoczął się nowy cykl wyborczy do rad dzielnic/osiedli. Wybory wyznaczono w 11 jednostkach pomocniczych na 22 kwietnia 2007 r. Zakończyły się one sukcesem - wybraniem rad osiedli w 9 jednostkach pomocniczych: Krakowiec-Górki Zachodnie (22,77\%), Wyspa Sobieszewska (12,91\%), Rudniki (15,11\%), Wzgórze Mickiewicza (11,79\%), Kokoszki (14,68\%), Strzyża (13,84\%), Osowa (12,98\%), Olszynka (12,71\%), Młyniska $(13,07 \%)$.

W związku z rezygnacją kandydata na radnego osiedla Letnica, wyborów w tej jednostce nie przeprowadzono. W Brzeźnie - 5,49\% frekwencja wyborcza była niewystarczająca (przy obowiązującym 10\% progu wyborczym), by wybory uznać za ważne.

Do końca kadencji Rady Miasta Gdańska w 2010 r. z powodzeniem przeprowadzono wybory do rad osiedli:

a) 30 września 2007 r. - do rady osiedla Letnica $(15,38 \%)$; 
b) 15 czerwca 2008 r. - do rady osiedla Nowy Port $(14,05 \%)$;

c) 4 października 2009 r. - do rady osiedla Żabianka-Wejhera-Jelitkowo-Tysiąclecia $(11,04 \%)$.

Natomiast porażkę ponieśli mieszkańcy Przymorza Małego (18 maja $2008 \mathrm{r}$. $-6,95 \%$ ) oraz Stogów (z Przeróbką) - (15 czerwca 2008 r. - 8,79\%), którym z jednej strony udało się zebrać wymaganą liczbę podpisów pod wnioskiem inicjującym funkcjonowanie rady, a z drugiej strony - nie potrafili wykorzystać tego poparcia przy urnie wyborczej.

Analizując wybory do jednostek pomocniczych Miasta Gdańska w latach 1997-2008 można stwierdzić, że:

a) liczba „uczestników wyborczych” (tj. jednostek pomocniczych) w kolejnych latach wzrastała, ale uczestniczyły tylko osiedla. W dzielnicach (jednostka powyżej 20000 mieszkańców) nie udało się zainicjować procesu wyboru rady dzielnicy;

b) brak czy nie do końca sprecyzowane stanowisko władz miasta wobec problemu funkcjonowania jednostek pomocniczych i ich władz. Dowodem może być wprowadzenie progu frekwencji wyborczej, którego nie ma w wyborach do organów samorządu terytorialnego oraz częstotliwość jego zmian;

c) w procesie uchwalania norm prawnych dla jednostek pomocniczych nie dało się zauważyć właściwej komunikacji między stronami: władze miasta-mieszkańcy. Przede wszystkim w niedostatecznym jego stopniu informowano o zamierzeniach, planowanych działaniach, projektach prawa lokalnego, a tym samym oddalono możliwość konsultowania tych zmian z zainteresowaną stroną - wspólnota mieszkańców;

d) wybory w jednostkach pomocniczych postrzegane były przez mieszkańców (ich większość) jako element ,gry politycznej”, ,etapu w dalszej karierze politycznej”, „szukaniu ciepłych posad”, „tworzeniu nic nieznaczących struktur, których utrzymanie będzie obciążało finanse miasta",

Ożywienie w zainteresowaniu, jak i funkcjonowaniu jednostek pomocniczych nastapiło po wyborach samorządowych z 12 listopada $2010 \mathrm{r}$. Władze miasta rozpoczęły działania mające na celu uaktywnienie mieszkańców do samoorganizacji, samodziałania, m.in. poprzez inicjowanie tworzenia rad dzielnic/osiedli, podejmowanie inicjatywy uchwałodawczej, czyli budowania społeczeństwa obywatelskiego ${ }^{6}$. Zainicjowano comiesięczne spotkania przedstawicieli władz miasta, urzędników samorządowych z mieszkańcami poszczególnych jednostek. Spotkania te miały, z jednej strony wykazać zainteresowanie, troskę, chęć niesienia pomocy władz miasta wobec mieszkańców, z drugiej zaś - z treści dyskusji dowiadywano się o codziennych problemach z jakimi borykają się mieszkańcy (np. niewłaściwa lokalizacja placów zabaw, śmietników, brak miejsc parkingowych itp.). Często „żywa i głośna” dyskusja obu stron wykazywał ogrom niewiedzy dyskutantów o wielu małych, ale jak istotnych problemach mieszkańców, spo-

\footnotetext{
${ }^{5}$ Fragmenty wypowiedzi mieszkańców pytanych o funkcjonowanie jednostek pomocniczych w Gdańsku na podstawie artykułów prasowych opublikowanych w dzienniku „Dziennik Bałtycki” z lat 2003-2008.

${ }^{6} \mathrm{~Np}$. wypowiedź Prezydenta Miasta Gdańska, Wszystko co chcielibyście wiedzieć o radach dzielnic..., www.adamowicz.pl, 26.11.2011.
} 
sobach ich rozwiązania. W tym kontekście dyskusji reprezentanci władz przekonywali o korzyściach wynikających z funkcjonowania rady dzielnicy/osiedla. Być może spotkania te przyczyniły się do przekonania mieszkańców o racjonalności powołania rad jednostek pomocniczych.

W kadencji Rady Miasta Gdańska (2006-2010) działało 13 rad osiedli w 30 jednostkach pomocniczych. W styczniu $2011 \mathrm{r}$. uprawomocnił się nowy podział administracyjny miasta na jednostki pomocnicze (Uchwała 2010, LII). „Rozdrobniono” 3 jednostki, tworząc z nich mniejsze terytorialnie i ludnościowo obszary:

a) ze Stogów (z Przeróbką) utworzono „Stogi” i „Przeróbkę";

b) Wrzeszcz podzielono na „Wrzeszcz Dolny” i „Wrzeszcz Górny”;

c) Chełm (z dzielnicą Gdańsk Południe) podzielono na „Jasien””, „Ujeścisko-Łostowice", „Chelm".

$\mathrm{Na}$ mapie administracyjnej Gdańska wykreślono 34 obszary terytorialne jednostek pomocniczych. W $2011 \mathrm{r}$. należało przeprowadzić wybory do rad osiedli, które już miały wybrane rady. Zgodnie z uchwałą wyborczą i przyjętym kalendarzem wyborczym, termin wyborów wyznaczono na 8 maja 2011 r. Równocześnie rozpoczęto zbieranie podpisów mieszkańców pod wnioskami o utworzenie jednostki pomocniczej. Zgodnie z zapisem Statutu Miasta Gdańska (§ 61.3) wniosek ten musi być podpisany przez co najmniej 10\% mieszkańców projektowanej jednostki.

Dnia 8 maja 2011 r. wybrano 27 rad: 22 rady osiedli (Rada Osiedla Brętowo, Rada Osiedla Brzeźno, Rada Osiedla Jasień, Rada Osiedla Kokoszki, Rada Osiedla Krakowiec-Górki Zachodnie, Rad Osiedla Letnica, Rada Osiedla Młyniska, Rada Osiedla Nowy Port, Rada Osiedla Oliwa, Rada Osiedla Olszynka, Rada Osiedla Orunia Św.-Wojciech-Lipce, Rada Osiedla Osowa, Rada Osiedla Przeróbka, Rada Osiedla Rudniki, Rada Osiedla Siedlce, Rada Osiedla Stogi, Rada Osiedla Strzyża, Rada Osiedla Ujeścisko-Łostowice, Rada Osiedla VII Dwór, Rada Osiedla Wyspa Sobieszewska, Rada Osiedla Wzgórze Mickiewicza, Rada Osiedla Żabianka-Wejhera-Jelitkowo-Tysiąclecia) i 5 rad dzielnic (Rada Dzielnicy Chełm, Rada Dzielnicy Piecki-Migowo, Rada Dzielnicy Sródmieście, Rada Dzielnicy Wrzeszcz Dolny, Rada Dzielnicy Wrzeszcz Górny).

Mieszkańcom osiedla Zaspa-Młyniec w wymaganym terminie (do 21 lutego 2011 r.) nie udało się zebrać odpowiedniej liczby podpisów. Na ich prośbę termin ten został wydłużony, co pozwoliło zebrać wymaganą liczbę podpisów i pozwoliło na dalsze procedowanie wniosku. Termin dodatkowych wyborów został wyznaczony na 25 września 2011 r., frekwencja wyniosła $13,32 \%$.

W 2011 r. na terenie miasta Gdańska funkcjonowało $28 \mathrm{rad}-23$ rady osiedli i $5 \mathrm{rad}$ dzielnic. Ponadto Rada Miasta Gdańska dwukrotnie zmieniła zapis uchwały wyborczej dotyczący progu frekwencji wyborczej. Uległ on obniżeniu z 10\% (w 2003 r.) na 8\% (w 2010 r.) (Uchwała 2011, VII) - ale w tym roku nie przeprowadzono żadnych wyborów do rad dzielnic/osiedli), a następnie na 5\% (w 2011 r.) (Uchwała 2011, VII).

Działania te polegające na ,drastycznym" obniżeniu progu frekwencji wyborczej pokazały, że władzom miasta zależy na aktywizacji członków wspólnot lokalnych i są chętne do pomocy, zmian, wprowadzania ułatwień. $Z$ drugiej strony - obnażono ułomność gdańskiej wspólnoty polegająca na braku więzi społecznych, integracji, chęci podejmowania decyzji, działań dla własnego dobra. 
W 5 dzielnicach - jednostkach powyżej 20000 mieszkańców, frekwencja wyborcza nie przekroczyła 10\%: Chełm (6,24\%), Piecki-Migowo $(8,30 \%)$, Śródmieście $(6,63 \%)$, Wrzeszcz Dolny (7,98\%), Wrzeszcz Górny (7,71\%). Gdyby nie przedwyborcza redukcja progu wyborczego, w tych dzielnicach nie utworzono by rad. Najlepszajakość obywatelskości wykazali mieszkańcy osiedla (osiedle domków jednorodzinnych) Wzgórze Mickiewicza $(22,97 \%)$, osiedla Strzyża $(19,96 \%)$, Przeróbka $(19,31 \%)$, Krakowiec-Górki zachodnie $(17,67 \%)^{7}$.

Władze miasta poza obniżeniem progu frekwencji wyborczej, zastosowały dość interesujące rozwiązanie zachęcające do uczestnictwa w wyborach. Radni miasta jednogłośnie podjęli uchwałę w sprawie wyodrębnienia na 2012 r. śodków finansowych na działalność statutową jednostek pomocniczych. Ustalono stawkę bazową na jednego mieszkańca w danej jednostce pomocniczej w wysokości 4,00 zł (Uchwała 2002, XLIX) ${ }^{8}$ (w 2010 r. - 3,50 zł), ale mogła ona zostać zwiększona. Wysokość „nowej” stawki uzależniona była od frekwencji w wyborach do rad dzielnic/osiedli w dniu 8 maja 2011 r., i tak:

a) jeśli w wyborach będzie uczestniczyło 14-16\% uprawnionych do głosowania, stawka bazowa wzrośnie o $25 \%$;

b) jeśli frekwencja przekroczy $16 \%$ - stawka bazowa wzrośnie o $50 \%$.

W ostatecznym rozrachunku jakość wyborów (frekwencja) przełożyły się na wynik ekonomiczny. Na 34 jednostki pomocnicze w 2011 r. wybrano 23 rady osiedli i 5 rad dzielnic. W 7 jednostkach frekwencja wyborcza przekroczyła 16\%, w 3 jednostkach zawierała się w przedziale 14-16\%, co skutkowało wzrostem środków finansowych na działalność statutową tych jednostek.

Kolejne wybory do rad dzielnic, zgodnie z zapisem Statutów Dzielnic ( $\$ 41)$,wybory do rad dzielnic zarządza Prezydent Miasta w terminie 2 miesięcy od złożenia ślubowania". Czyli po jesiennych wyborach samorządowych (16 listopada 2014 r.), wybory do rad dzielnic miasta Gdańska wyznaczono na 22 marca 2015 r. Wybory te miały odbyć się w 30 z 34 jednostek. Ostatecznie przeprowadzono je w 29 dzielnicach, gdyż 2 dni przed wyborami kilku kandydatów zrezygnowało z kandydowania do rady dzielnicy VII Dwór, powodując wstrzymanie procesu wyborczego ${ }^{9}$. W czterech dzielnicach administracyjnych (w których nie funkcjonują organy władzy): Matarnia, Przymorze Małe, Suchanino, Zaspa-Rozstaje nie przeprowadzono wyborów, gdyż mieszkańcy tych jednostek nie wykazali się inicjatywą utworzenia rady dzielnicy.

\footnotetext{
${ }^{7}$ Wyniki wyborów do rad jednostek pomocniczych miasta Gdańska, www.mojemiasto.pl, 27.11.2012.

${ }^{8}$ Wielkość środków finansowych jest określana według liczby stałych mieszkańców jednostki pomocniczej w dniu 30 września roku poprzedzającego. W przypadku przeprowadzenia pierwszych wyborów do organów nowo powołanej jednostki pomocniczej w trakcie roku budżetowego, środki przeznaczone na działalność statutową tej jednostki ustala się w tym roku budżetowym jako iloczyn pełnych miesięcy od dnia wyborów do końca danego roku i 1/12 kwoty wyliczonej według określonych zasad $(\S 23)$.

${ }^{9}$ Zgodnie z zapisem w Statutach dzielnic $(\$ 56)$ wybory przeprowadza się, jeżeli liczba zgloszonych kandydatów jest większa od ustalonej liczby mandatów dla dzielnicy. W przypadku rezygnacji kandydatów liczba zgłoszonych (pozostających na liście) była mniejsza od liczby wymaganej - 15 osób, co skutkowalo wstrzymaniem procesu wyborczego.
} 
Nowym rozwiązaniem przyjętym na potrzeby przeprowadzenia wyborów do rad dzielnic, była zmiana wszystkich Statutów dzielnic, polegająca na dopisaniu rozdziału 6 a "Zasady i tryb przeprowadzania wyborów do rady Dzielnicy" (tym samym zniesiono uchwałe, ,wyborczą") oraz zmianie zasad wybierania. W wyborach 2015 r. zmieniono zasadę oddawania głosów - ,wyborca oddaje tylko 1 głos na kandydata” (§ 66). W latach wcześniejszych oddawano głos na kilku kandydatów. Zmiana ta miała na celu ,polepszenie jakości wyborów", miała zmotywować kandydatów do rywalizacji, prowadzenia merytorycznej kampanii wyborczej, a dla wyborców - oddać głos na (ich zdaniem) najlepszego kandydata.

Wyniki wyborów, frekwencja wyborcza w wyborach do rad dzielnic są dowodem jakości społeczności lokalnej. W 2015 r. mieszkańcy Gdańska niechętnie uczestniczyli w wyborach swoich przedstawicieli. Najczęstszym powodem nieuczestnictwa było: brak wiedzy o funkcjonowaniu rad dzielnic, odbywających się do nich wyborach, informacji o terminie wyborów, kandydatach, mylenie wyborów ogólnopolskich samorządowych z ,samorządowymi lokalnymi”. Z pewnościąźle przygotowane i przeprowadzone procedury wyborcze w wyborach do organów stanowiących jednostek samorządu terytorialnego oraz na wójta, burmistrza i prezydenta miasta, szum medialny, chaos przy ogłaszaniu wyników wyborów, spowodowały zniechęcenie, a tym samym brak zainteresowania wyborami do rad dzielnic. Kampania wyborcza kandydatów na radnych dzielnicowych najczęściej polegała na rozdaniu ulotek (bardzo skromna ich liczba), wywieszeniu plakatów, baner (np. wspólne zdjęcie wszystkich kandydatów do rady dzielnicy Strzyża). Kampania ta była prawie niezauważalna, co można tłumaczyć jej kosztami pokrywanymi z środków własnych kandydata. Media lokalne dość ogólnikowo informowały o przygotowaniach do wyborów do rad dzielnic, np. gazeta „Dziennik Bałtycki Polska” na dalszych stronach informowała o funkcjonowaniu jednostek pomocniczych, przygotowaniach do wyborów.

Frekwencja wyborcza do 29 rad dzielnic była zróżnicowana. Najniższą zanotowano w dzielnicach: Śródmieście (6,33\%), Ujeścisko-Łostowice $(7,33 \%)$, Jasień $(7,34 \%)$, Piecki-Migowo (7,35\%). Najwięcej uprawnionych do głosowania uczestniczyło w wyborach do rady dzielnicy; Strzyża (23,32\%), Wzgórze Mickiewicza (20,39), Kokoszki $(19,65 \%)$, Brętowo $(19,05 \%)$, Osowa $(18,54 \%)$. Zastanawiające jest, dlaczego w dużych dzielnicach (tzw. sypialnie Gdańska) zlekceważono wybory. Np. w dzielnicy Śródmieście na 23404 osoby uprawnione do głosowania, tylko 1478 osób uczestniczyło w wyborach (to 307 osób więcej niż wynosił próg wyborczy); do 21-osobowej rady dzielnicy kandydowało 30 osób, w tym zwycięzca otrzymał 152 głosy poparcia, kandydat zamykający listę ,zwycięzców” otrzymał 28 głosów. Analiza wyników wyborów w poszczególnych dzielnicach pokazuje, że łatwo można było zostać zwycięzca, wystarczyło kilka głosów poparcia, np. uzyskały mandat osoby, które otrzymały 1 głos (Krakowiec-Górki Zachodnie), 2 głosy - Rudniki, 3 głosy - Młyniska.

Ponadto, władze miasta Gdańska zastosowały gratyfikację finansową dla rad osiedli za „frekwencję wyborcza”" Powtórzono rozwiązanie przyjęte dla wyborów z 2011 r., gdy kwota środków finansowych na funkcjonowanie jednostki pomocniczej była zwiększana, jeśli frekwencja wyborcza przekroczyła próg 14, bądź 16\%. Rozwiązanie to miało stać się motywatorem do uczestniczenia w wyborach, ale jak wskazują wyniki (wysokość frekwencji wyborczej) tylko kilku dzielnicom uda się pozyskać dodatkowe środki finansowe. 


\section{Wladze rad dzielnic}

Model ustroju i funkcjonowania dzielnic i osiedli określa rada Miasta Gdańska. Zgodnie z zapisem Statutu Miasta Gdańska (§ 61.2), ,organizację i zakres działania jednostek pomocniczych określa rada odrębnym statutem, po przeprowadzeniu konsultacji z mieszkańcami. Statut jednostek pomocniczych określa w szczególności: 1) nazwę i obszar jednostki pomocniczej, 2) zasady i tryb wyborów organów jednostek pomocniczych, 3) organizację i zadania organów jednostek pomocniczych, 4) zakres zadań przekazywanych jednostkom przez Miasto oraz sposób ich realizacji, 5) zakres i formy kontroli oraz nadzoru rady nad działalnością organów jednostek pomocniczych".

Samą organizację i zakres działania jednostek pomocniczych określiła Rada Miasta, uchwalając odrębne statuty dzielnic i osiedli. Dla gdańskich jednostek pomocniczych zastosowano dość osobliwe rozwiazzanie co do uchwalania statutów. Projekt statutu jest efektem pracy zespołu składającego się przedstawicieli jednostek pomocniczych, Prezydenta Miasta Gdańska oraz radnych. W projekcie tym uwzględnia się uwagi zgłaszane $\mathrm{w}$ trakcie konsultacji społecznych z mieszkańcami. Według założeń w treści statutu unika się nadmiernej szczegółowości na rzecz rozwiązań uniwersalnych, ma on być funkcjonalny. W takim kierunku zaczęto zmieniać już obowiązujące statuty dzielnic/osiedli.

Obecnie uchwalono statuty dla wszystkich 34 jednostek, chociaż funkcjonuje tylko 28 rad jednostek pomocniczych. Zabieg ten ma zachęcić mieszkańców 6 jednostek pomocniczych do podjęcia działań inicjujących powołanie rady osiedla.

Należy pamiętać, iż ustawa o samorzq̨dzie gminnym wymienia organy jednostek pomocniczych; organem uchwałodawczym w dzielnicy (osiedlu) jest rada, organem wykonawczym - zarząd, na czele którego stoi przewodniczący. Stąd nazewnictwo organów jednostek pomocniczych dzielnic/osiedli (czy innych) jest ujednolicone. Gdańskie rady dzielnic liczą 21 radnych, osiedlowe - 15. Rada ze swojego grona wybiera przewodniczącego rady i 1 zastępcę przewodniczącego, moga powoływać (i odwoływać) stałe i doraźne komisje do realizacji określonych zadań. Obowiązkowo powołaną i działającą komisją jest komisja rewizyjna (w składzie nie mniejszym niż 3 osoby), której celem jest kontrola działalności zarządu.

Funkcje organu wykonawczego pełni kolegialny zarząd, składający się z: przewodniczącego zarządu, 1 zastępcy oraz 2 członków zarządu. Liczbę członków zarządu ustala rada, na wniosek przewodniczącego zarządu. Przyjęcie takiego rozstrzygnięcia prawnego pozwala na zróżnicowanie składu zarządu (liczby członków zarządu) do potrzeb, realizowanych zadań.

Działalność w organach jednostek pomocniczych ma charakter społeczny. Diety $z$ tytułu pełnionych funkcji otrzymują:

a) przewodniczący zarządu $-600,00 \mathrm{zł}$,

b) jego zastępca - 300,00 zl,

c) członek $-300,00 \mathrm{zl}$,

d) przewodniczący rady dzielnicy/osiedla $-300,00 \mathrm{zł}$ (Uchwała, 2003, VIII).

Ponadto władze miasta zapewniają warunki lokalowe na siedziby władz jednostek oraz obsługę finansową i techniczno-kancelaryjną. Koszty utrzymania lokali (głównie są to lokale będące własnością miasta), opłaty za media, telefon pokrywa się ze środków finansowych miasta. Wynoszą one ok. 500-700 tys. zł rocznie. Dwa razy do roku radni 
jednostek pomocniczych otrzymują tzw. pakiet materiałów biurowych oraz środki czystości. Mają możliwość korzystania z zaplecza administracyjno-biurowego urzędu miasta, co dodatkowo generuje koszty.

Statuty rad dzielnic/osiedli zawierają szczegółowe rozwiązania odnoszące się do trybu i zasad wyboru organów, gospodarki finansowej, nadzoru nad działalnością dzielnic/osiedli, składania przez organy jednostek pomocniczych sprawozdań przed mieszkańcami.

Interesującym rozwiązaniem było powołanie pełnomocników Prezydenta Miasta Gdańska ds. współpracy z jednostkami pomocniczymi (Zarządzenie, 2010, 528) w $2010 \mathrm{r}$. Ideą tego przedsięwzięcia było ułatwienie współpracy, kontaktów między mieszkańcami, organizacjami działającymi na obszarze jednostki pomocniczej a aparatem administracji samorządowej. Instytucja ta została zniesiona w $2013 \mathrm{r}$. Uznano, że rady dzielnic/osiedli zostały wyposażone w wiele narzędzi ułatwiających im funkcjonowanie i dodatkowa osoba „skomplikuje” proces komunikowania się.

\section{Podsumowanie}

Najnowszym rozwiązaniem przyjętym dla jednostek pomocniczych było uchwalenie uchwaly w sprawie zmiany Statutu Miasta Gdańska, w której ujednolicono nazewnictwo jednostek pomocniczych (Uchwała, 2014, XLVIII). Przepis ten obowiązuje od 1 czerwca 2014 r. i wprowadza nazwę "dzielnica” dla wszystkich 34 jednostek. Argumentem za zmianą nazwy było pejoratywne kojarzenie „osiedla" ze spółdzielnią mieszkaniową, dawnymi komitetami osiedlowymi, radami narodowymi osiedli.

Zmieniono zapis o wielkości - liczbie mieszkańców dzielnicy, określając, że „na obszarze dzielnicy musi zamieszkiwać nie mniej niż 2 tys. mieszkańców” (§1).

Przyjęta regulacja stała się kontrowersyjna, gdyż na terenie miasta Gdańska funkcjonują 3 jednostki, których liczba mieszkańców nie przekracza 2 tys. Należą do nich: Krakowiec - Górki Zachodnie (1958 mieszkańców), Letnica (1338), Rudniki (1354). Odpowiednie wnioski zostały skierowane do wojewody i w przyszłości podjęte zostanie właściwe rozstrzygnięcie.

Jednostki pomocnicze miasta Gdańska stały się trwałym elementem w jego przestrzeni. Przyjęte rozwiązania prawne nie obligują władz miasta do tworzenia jednostek pomocniczych (np. w Gdyni jest obowiązek powoływania jednostek pomocniczych), ale kwestie te są wynikiem oddolnego działania mieszkańców. Jednostka pomocnicza miasta może zostać powołana na wniosek co najmniej $10 \%$ mieszkańców jednostki uprawnionych do wyborów do Rady Miasta Gdańska. Stąd na terenie Gdańska nie wszystkie jednostki pomocnicze (podział administracyjny) mają swoje wybieralne organy. Mechanizm kształtowania instytucji jednostek pomocniczych stał się formą partycypacji obywateli w życiu gminy. Specyficzne funkcjonowanie gdańskich jednostek pomocniczych polega na ich ciagłej przemianie, spowodowanej zmianami prawa lokalnego, poszukiwaniem ,idealnych" rozwiązań. Zadawalające jest to, iż wiele poczynań władz miasta zmierza do ustabilizowania i poprawy jakości funkcjonowania jednostek pomocniczych.

Sukces czy porażka społeczności lokalnych? - czy funkcjonowanie jednostek pomocniczych pomaga w kształtowaniu się lepszej jakości społeczeństwa? Wydaje się, że mecha- 
nizm oddolnego sprawowania władzy (rady dzielnic), podejmowanie przez mieszkańców działań zmierzających do poprawy jakości życia powinny przyczynić się do zwiększenia partycypacji mieszkańców w ,zarządzaniu” dzielnicą. Z jednej strony, przyzwolenie i pomoc władz miasta na działanie rad dzielnic powinny służyć ich rozwojowi. Z drugiej zaś strony, władze miasta przejmują rolę koordynatora i zarządcy podejmowanych działań w dzielnicach, często bez wsparcia mieszkańców. Z pewnością proces kształtowania się społeczności lokalnych wymaga czasu. Ocenić jak działają rady dzielnic miasta Gdańska będzie można dopiero za kilka lat, gdy proces ten na dobre stanie się elementem ksztaltowania wspólnoty lokalnej.

\section{Bibliografia}

„Dziennik Bałtycki Polska” (2003-2008)

Słobodzian B. (2007), Wspólczesny system samorzadu terytorialnego w Polsce, Wydawnictwo Adam Marszałek, Torun.

Uchwała 1992, XLI/348 Rady Miasta Gdańska z 30.07.1992 r. w sprawie utworzenia jednostek pomocniczych Miasta Gdańska w postaci dzielnic/osiedli.

Uchwała 1992, XLIX/350 Rady Miasta Gdańska z 30.07 .1992 r. w sprawie zasad i trybu przeprowadzania wyborów do rad dzielnic/osiedli.

Uchwała 1992, LV/396 Rady Miasta Gdańska z 21.11.1992 r. w sprawie zmiany Uchwaty Nr XLLX/348/92 Rady Miasta Gdańska z 30.07.1992 r. w sprawie utworzenia jednostek pomocniczych Miasta Gdańska w postaci dzielnic/osiedli.

Uchwała 1993, LIX/436 Rady Miasta Gdańska z 16.02.1993 r. w sprawie zmiany Uchwaty Nr XLLX/348/92 Rady Miasta Gdańska z 30.07.1992 r. w sprawie utworzenia jednostek pomocniczych Miasta Gdańska w postaci dzielnic/osiedli.

Uchwała 1995, XXIII/232 Rady Miasta Gdańska z 27.07.1995 r. w sprawie zmiany Uchwaty Nr XLLX/348/92 Rady Miasta Gdańska z 30.07 .1992 r. w sprawie utworzenia jednostek pomocniczych Miasta Gdańska w postaci dzielnic/osiedli.

Uchwała 1997, XLV/542/97 Rady Miasta Gdańska z 20.02.1997 r. w sprawie zmiany Uchwaty Nr XLLX/348/92 Rady Miasta Gdańska z 30.07 .1992 r: w sprawie utworzenia jednostek pomocniczych Miasta Gdańska w postaci dzielnic/osiedli.

Uchwała 1998, LXII/848 Rady Miasta Gdańska z 16.06.1998 r. w sprawie określenia organizacji zakresu dzialania oraz trybu przeprowadzania wyborów do jednostek pomocniczych Miasta Gdańska w postaci dzielnic/osiedli.

Uchwała 1999, LX/319 Rady Miasta Gdańska z 29.04.1999 r. w sprawie zmiany Uchwaly Nr LXII/848/98 Rady Miasta Gdańska z 16.06.1998 r. w sprawie określenia organizacji zakresu dzialania oraz trybu przeprowadzania wyborów do jednostek pomocniczych Miasta Gdańska w postaci dzielnic/osiedli.

Uchwała 2002, XLIX/1488 Rady Miasta Gdańska z 23.05.2002 r. w sprawie określenia organizacji, zasad finansowania oraz zakresu dziatania jednostek pomocniczych Miasta Gdańska.

Uchwała 2003, VIII/191 Rady Miasta Gdańska z 24.04.2003 r. zmieniajaca uchwalę w sprawie zasad i trybu przeprowadzania wyborów do rad jednostek pomocniczych.

Uchwała 2003, VIII/192/03 Rady Miasta Gdańska z 2.04.2003 r. w sprawie ustalenia wysokości diet stużbowych dla przewodniczacych rady, przewodniczacych zarzadu rady jednostek pomocniczych Gdańska.

Uchwała 2010, LII/1462/10 Rady Miasta Gdańska z 28.10.2010 r. zmieniajqca Uchwate nr XLIX/348/92 Rady Miasta Gdańska z 30.07.1992 r. w sprawie utworzenia jednostek pomocniczych Miasta Gdańska w postaci dzielnic/osiedli. 
Uchwała 2011, VII/89/11 Rady Miasta Gdańska z 17.02.2011 r. zmieniajaca uchwate w sprawie zasad i trybu przeprowadzania wyborów do rad jednostek pomocniczych.

Uchwała 2014, XLVIII/1073/14 Rady Miasta Gdańska z 16.01.2014 r. w sprawie zmian Statutu Miasta Gdańska.

Wyniki wyborów do rad jednostek pomocniczych miasta Gdańska, www.mojemiasto.pl, 27.11.2012, 29.03.2015.

Zarządzenie 2010, 528/10 Prezydenta Miasta Gdańska z 19.04.2010 r. w sprawie powolania Pelnomocników ds. wspótpracy z jednostkami pomocniczymi Miasta Gdańska.

Uchwała 2014, XLVIII/1073/14 Rady Miasta Gdańska z 16.01.2014 r. w sprawie zmian Statutu Miasta Gdańska.

Ustawa z 8 marca 1990 r. o samorzadzie gminnym, tekst jednolity Dz. U. 2013, Nr 594, poz. 1318 ze zm.

\section{Success or failure? The functioning of auxiliary units on the example of the city of Gdańsk}

\section{Summary}

The auxiliary units of Gdansk have become a permanent element of its structure. On the basis of the adopted legal measures, local authorities are not obliged to establish auxiliary units (but in Gdynia it is obligatory to appoint auxiliary units), but it follows from the grassroots activities of citizens. The mechanism of forming auxiliary units has become a means of inhabitants participating in municipal life. The unique functioning of the Gdańsk auxiliary units relies on their ongoing transformation, caused by multiple amendments of local laws. The above is a result of searching for the best solutions. Above all, multiple actions undertaken by the local government are focused on the stabilisation, as well as improvement of the functioning of auxiliary units.

Key words: local government, auxiliary units, participation 